\title{
APROXIMAÇÕES AO LIVRO-ÁLBUM LÍRICO CONTEMPORÂNEO PORTUGUÊS E BRASILEIRO: UMA ANÁLISE COMPARADA
}

APPROACHES TO THE PORTUGUESE

AND BRAZILIAN CONTEMPORARY LYRIC

PICTUREBOOK: A COMPARATIVE ANALYSIS

Ana Margarida Ramos'

ORCID 0000-0001-5126-4389

Margareth Mattos ${ }^{2}$

ORCID 0000-0002-4604-467X

${ }^{1}$ Universidade de Aveiro Aveiro, Portugal

${ }^{2}$ Universidade Federal Fluminense

Niterói, RJ, Brasil

\section{Resumo}

Pretende-se, com este estudo, analisar um conjunto de livros-álbum líricos contemporâneos, publicados em Portugal e no Brasil, com vista a identificar as características deste tipo de publicaçóes e a refletir sobre as especificidades da relação texto-ilustração-suporte na criação de sugestôes de leitura poético-líricas, procedendo à sua distinção em relação aos livros-álbum narrativos. Ao mesmo tempo, dá-se conta do estado da arte sobre o livro-álbum lírico, quer em termos de estudos e de investigação, quer em termos criativos, analisando o seu relevo no panorama editorial dos dois países.

Palavras-chave: álbum-lírico, ilustração, imagem, suporte.

\section{Abstract}

The aim of this study is to analyse a set of contemporary poetic picturebooks published in Portugal and Brazil in order to identify the characteristics of this type of publications and to reflect upon the specificities of the textillustration-support relationship in the creation of the poetic suggestion, which distinguishes lyric picturebooks from narrative picturebooks. At the same time, the study presents the actual panorama

\section{Resumen}

La intención de este estudio es analizar um conjunto de libros-álbum líricos contemporáneos, publicados en Portugal y en Brasil, para identificar los rasgos de este tipo de publicación y reflexionar sobre las especificidades de la relación texto-ilustración-soporte en la creación de sugerencias de lectura poético-líricas, procediendo a su distinción en relación a los libros-álbum narrativos. A la vez, se da cuenta del estado del arte del libro-álbum 
of lyrical picturebooks, in Portugal and Brazil, in terms of creation and research, highlighting its importance in the editorial landscape of both countries.

Keywords: poetic picturebook, illustration, image, support. lírico, sea en términos de estudios y de investigación, sea en términos creativos, analizando su relevancia en el panorama editorial de los dos países.

Palabras clave: libro-album lírico, ilustración, imagen, soporte.

\section{Introdução}

Com pouca tradição na edição em língua portuguesa, sobretudo quando comparado com o narrativo, o livro-álbum lírico (RAMOS, 2011), enquanto tipologia específica dentro do universo do livro-álbum, tem sido objeto de estudos pontuais, quase todos circunscritos aos trabalhos de Sara Reis da Silva (2011; 2017¹), em Portugal, e María del Rosario Neira-Piñeiro (2012; 2013; 2018) em Espanha, por um lado sublinhando o interesse e as possibilidades de leitura deste formato, e por outro definindo-o pela ausência de narratividade e sequencialidade na organização estrutural. Aliás, esta última autora tem dedicado uma sucessão de estudos de fôlego ao livroálbum lírico, não só procurando descobrir as suas especificidades enquanto modalidade editorial, mas também classificando as diferentes tipologias em que se divide. Num dos seus estudos mais recentes (NEIRA-PIÑEIRO, 2018), a investigadora espanhola analisa e classifica as diferentes formas de relação entre texto e imagem nestes livros, identificando uma variedade de procedimentos que não excluem os códigos visuais do álbum narrativo, tendo em vista processos de aproximação ao público-alvo. Contudo, são igualmente recorrentes procedimentos específicos do universo poético-lírico, associados a paralelismos e repetiçóes, tendo em vista a sugestão de ritmos, mas também a metáfora tanto verbal quanto visual, por exemplo. Donelle Ruve (2018), por seu turno, estuda as relaçôes entre a poesia e a ilustraçáo ${ }^{2}$ (e as artes visuais), analisando um conjunto de publicações desde o século XIX. Assim, a autora distingue, baseando-se na ordem de criação e na relação estabelecida entre as linguagens, a ilustração de poemas previamente existentes da écfrase. Ambos subgêneros são diferentes da criação em conjunto de poemas e imagens, cujo pioneirismo atribui a William Blake. Num registo diferente, destaca as criaçôes clássicas de Edward Lear, seguidas por uma plêiade de poetas onde se incluem, por exemplo, Shel Silverstein, Dr. Seuss ou JonArno Lawson. Em todo o caso, a reflexão desta autora afasta-se de forma visível do formato do livro-álbum, incidindo sobretudo em coletâneas ilustradas de poesia.

1 Esta publicação foi realizada em coautoria. Ver Silva \& Selfa Sastre, 2017.

2 Sobre o relevo e as especificidades da ilustraçấo de poesia, nomeadamente a infantil, ver também Camargo (1998) e Ramos (2014). 
Para uma definição do livro-álbum lírico:

quando o objetivo não é contar uma história

Sara Reis da Silva refere-se à criação de álbuns poéticos como uma "tendência recente e ainda emergente" (SILVA, 2011, p. 282), sublinhando, como elementos determinantes para a definição do gênero a existência de "um único texto cujos elementos componentes ou os versos surgem disseminados ao longo do volume, decorrendo desta opção estético-semântica uma 'tensão' entre uma arquitectura visual fragmentada e uma unidade e/ou integridade verbal essencial" (SILVA, 2011, p. 282), para além da "cooperação especial" (idem) entre palavras e imagens, aspeto comum a todo o tipo de livros-álbum. A brevidade, a contenção, a fragmentação e a descontinuidade dos textos, com impacto ao nível do tratamento visual e gráfico, são outros elementos referidos pela investigadora como transversais a publicaçóes que tiram partido das omissóes, do não dito e do vazio.

Para Neira-Pińeiro, por seu turno, "o álbum lírico caracteriza-se pela combinação de um ou vários poemas com uma sequência de imagens, de forma que ambos interatuam na criação de sentido"3 $(2018$, p. 56). A tipologia de livros-álbum líricos que apresenta (NEIRA-PIÑEIRO, 2012) inclui, por um lado, as publicaçôes de tipo antológico, que incluem vários poemas, e, por outro, os livros-álbum que incluem um poema único, distribuído pelas várias páginas, por ela denominados álbuns poemas. Cada um destes dois grandes tipos pode apresentar alguns subtipos, tendo em conta as relaçóes estabelecidas entre as componentes verbal e visual e a própria construção/ arquitetura de cada volume.

As publicaçóes de tipo antológico são identificadas pela autora em três subtipos: as antologias, os poemários e os álbuns-jogo. Esses subtipos têm em comum a reuniáo de vários poemas combinados com imagens. O que distingue o álbum antologia do álbum poemário é a situação temporal do paratexto das obras de um ou outro subtipo. Enquanto o álbum antologia reúne textos poéticos preexistentes, ou seja, textos de um só poeta ou de diferentes poetas já publicados anteriormente - em geral, de autoria de poetas clássicos ou consagrados, ou mesmo da lírica tradicional -, o álbum poemário reúne poemas combinados com imagens em uma edição original, ou seja, os poemas e as formas visuais são criadas especialmente para o álbum. O subtipo livro-álbum jogo, por sua vez, distingue-se dos demais pela sua dimensão eminentemente lúdica, sendo imprescindíveis as componentes verbal e visual em estrita colaboração, tanto para a interpretação do álbum quanto para a realização do jogo proposto.

3 Traduçáo das autoras do texto original: "el álbum lírico se caracteriza por la combinación de uno o vários poemas con una secuencia de imágenes, de forma que ambos interactúan en la creación de sentido”. 
Outras características comuns a estes três subtipos são a relevância da componente visual e o elevado grau de autonomia das unidades mínimas formadas por poema e imagem, o que faz com que se possa ler cada unidade de modo independente, a despeito da homogeneidade estética ou temática do álbum.

Já as publicaçôes de tipo álbum poema são identificadas em dois subtipos: álbum poema a partir de texto poético preexistente, e álbum poema a partir de texto poético criado especificamente para o álbum. Nesse caso, novamente, é a situação temporal dos paratextos o critério para o estabelecimento dos subtipos. Quando se trata de obra do primeiro subtipo, em geral, a autoria da componente visual é necessariamente diferente da autoria da componente verbal. No segundo subtipo, a autoria dessas componentes pode ser a mesma ou náo.

A principal característica comum a esses dois subtipos do álbum poema é a sequência advinda de certo teor narrativo, que tanto pode estar presente na componente verbal quanto na visual. Assim, em poemas líricos que encerram certa narratividade, a sequência de imagens estará relacionada com esse atributo. Já nos poemas nos quais a sequência narrativa não existe, a narratividade será desenvolvida, necessariamente, na componente visual.

Outras aproximações teóricas possíveis são as propostas por Glazer e Lamme (1990), centradas no uso, em contexto didático, do livro-álbum poético, mas as autoras também procuram caracterizar este tipo de publicaçóes, destacando as afinidades entre o discurso poético e o formato do livro-álbum ilustrado, na medida em que as imagens que acompanham os textos podem reforçar a sua mensagem poética, mas também o lirismo do próprio registo. Além disso, no caso dos livros-álbum que só apresentam um poema, o texto ganha um impacto e uma visibilidade que habitualmente não tem quando inserido numa coletânea, o que conduz a uma leitura mais atenta e mais demorada e, logo, mais profunda. As autoras distinguem, contudo, vários tipos de propostas, como é o caso das "ediçôes de livros-álbum de uma única história escrita em verso, letras de cançōes e rimas infantis" “ (GLAZER E LAMME, 1990, p. 104). Ted Kesler (2012), por seu turno, dedica-se ao estudo dos "Livros-álbum poéticos não ficcionais", que define como "uma forma cada vez mais predominante de texto híbrido é a convergência da não-ficção infantil e da poesia sob a forma de livros-álbum"6 (KESLER, 2012, p. 340), o que corresponde a um tipo muito específico de proposta editorial sobre

\footnotetext{
4 Tradução das autoras do texto original: "picture book editions of single stories written in verse, song lyrics, and nursery rhymes"

5 "Poetic Nonfiction Picture Books"

6 Traduçáo das autoras do texto original: "an increasingly prevalent form of hybrid text is the convergence of children's nonfiction and poetry in the form of picture books"
} 
a qual não nos debruçaremos neste momento, mas que merece pelo menos referência da sua existência e interesse investigativo.

O livro-álbum lírico em Portugal e no Brasil: contributos para uma história breve

Em Portugal, a publicação de livros suscetíveis de aproximação ao universo do álbum lírico é consideravelmente recente, e decorre da atividade de alguns criadores em particular, ao nível tanto do texto como das ilustraçóes, exigindo um diálogo particular entre ambos. Em 2005, a publicação de Palavra que voa (Caminho), de João Pedro Mésseder e Gémeo Luís, um volume muito original onde um único poema surge fragmentado ao longo do livro, dividindo o protagonismo com os depurados recortes do ilustrador, pode ser considerado como pioneiro. Seguiram-se volumes como $O$ Quê Que Quem (Ediçôes Eterogémeas7, 2005), de Eugénio Roda e Gémeo Luís, Letras \& Letrias (Dom Quixote, 2005), de José Jorge Letria e André Letria, O Pê de Pai (Planeta Tangerina, 2006), de Isabel Minhós Martins e Bernardo Carvalho, O Mar (Gatafunho, 2008), de Luísa Ducla Soares e Pedro Sousa Pereira, Linguas de Perguntador (Paulinas, 2009), de João Pedro Mésseder e Madalena Matoso, Gente? (Calendário, 2011), de João Pedro Mésseder e Daniel Silvestre da Silva, ou Se eu fosse um livro (Pato Lógico, 2011), de José Jorge Letria e André Letria, por exemplo.

Em comum, esses volumes apresentam, para além dos textos com características formais e temáticas próprias do texto poético, como o uso do verso e da rima, "la presencia de um discurso fuertemente subjetivizado, centrado en la expresión de emociones, sentimentos, pensamentos o una vision particular del mundo atribuída al yo poético" (NEIRA-PIÑEIRO, 2012, p. 133). Elementos como a depuração linguística, a valorização da palavra nas suas dimensôes sonoras, gráficas, semânticas e lúdicas, o jogo metafórico ou a valorização da introspeção, por exemplo, também colaboram na distinção destes livros dos seus congéneres narrativos.

O volume Um livro para todos os dias (Planeta Tangerina, 2004), de Isabel Minhós Martins e Bernardo Carvalho, que marcou a estreia da editora no segmento infantojuvenil, apresenta já indícios da poeticidade - que resulta de uma certa reflexão introspetiva e filosófica sobre a vida, o tempo e a condição humana - que marcará obras posteriores, como Quando eu nasci (2007), Coração de Mãe (2008) Para onde vamos quando desaparecemos? (2011), todos de Isabel Minhós Martins, com ilustraçóes de Madalena Matoso, o primeiro e o último, e Bernardo Carvalho, o segundo.

7 Nesta editora, vários textos narrativos de Eugénio Roda, escrito em prosa poética, foram sendo publicados num formato próximo do do livro-álbum, como foi o caso de Azul, blue, bleu (2009), Berlinde, bille, marble (2009), Catavento (2010), entre outros, aproximando-se, amiúde, do universo poético-lírico. 
Nos últimos anos, o número e a variedade de propostas têm vindo a alargar-se, incluindo, por exemplo, a transformação de letras de cançôes em livro-álbum, como aconteceu com o poema O Primeiro Gomo da Tangerina (Planeta Tangerina, 2010), de Sérgio Godinho, visual e graficamente recriado por Madalena Matoso, ou o poema Imagem (Planeta Tangerina, 2016), de Arnaldo Antunes, com ilustrações e design de Yara Kono. Também a publicação do volume Como tu (QuidNovi, 2012), de Ana Luísa Amaral e Elsa Navarro, assinala um marco relevante da ediçáo, na medida em que se trata de um volume muito original no qual um poema longo, e apresentado sob a forma dialogada, é fragmentado em partes, e cuja leitura é completada também pelo lirismo visual das ilustraçóes, que recriam e complementam o texto, procedendo à sua releitura. Mais recentemente, a edição de $A$ palavra perdida (Arranha-Céus, 2014), de Inês Fonseca Santos e Marta Madureira, também cria fissuras numa definição mais fechada de livro-álbum lírico (cruzando-o com o narrativo, mas também com o jogo), na medida em que a narrativa de cariz mais convencional é entrecortada por reflexóes de cariz metaliterário e metalinguístico sobre a palavra e as suas potencialidades, em estreito diálogo com as imagens onde se esconde (e se descobre) a palavra perdida.

Resultante do diálogo colaborativo entre José Jorge Letria e André Letria, o volume A Guerra (Pato Lógico, 2018) constitui uma proposta literária interessante na medida em que texto e imagem potenciam as leituras decorrentes das duas linguagens que se cruzam num livro que denuncia todas as guerras e as suas consequências e motivaçóes, apelando implicitamente a uma cultura de paz.

No Brasil, as publicações Olha o bicho (Ática, 1989), de José Paulo Paes e Rubens Matuck, e Poemas para brincar (Ática, 1990), de José Paulo Paes e Luiz Maia, ambos álbuns poemários, uma vez que os componentes verbal e visual foram criados especialmente para o álbum, podem ser consideradas precursoras deste subtipo de livro-álbum lírico, seja pelo modo de interação entre palavra e imagem, seja pelas características dos seus paratextos, já que ambas as brochuras, em dimensóes pouco usuais (formato retrato $215 \mathrm{~mm} \mathrm{x}$ $375 \mathrm{~mm}$ ), possibilitam a exploração da dupla página, onde as formas visuais sobressaem, e onde os créditos de autoria dos poemas e das ilustraçóes estão dispostos, em suas respetivas capas e folhas de rosto, de forma simétrica, sugerindo a equivalência do valor da produçáo dos componentes poético e visual. Em uma e outra obra, o poeta José Paulo Paes explora figuras e jogos de linguagem variados, provocando "o prazer da estranheza" (BORDINI, 1986, p. 13) no leitor infantil. Em Olha o bicho, cada poema é impresso com uma cor diferente, harmonizando-se com a cor predominante das formas visuais com que se conjuga. Nesse sentido, o paralelismo entre palavra e imagem é estabelecido não só pelo tema de cada poema, mas também pela 
cor empregada na impressão da unidade poema-ilustração. Em Poemas para brincar, o ludismo alia-se ao humor e ao nonsense em cada uma de suas unidades mínimas, que ocupam ora páginas simples, ora páginas duplas.

Aprodução de livros-álbum líricos, na sua quase totalidade livrosálbum antologias e poemários (NEIRA-PIÑEIRO, 2012), intensifica-se a partir dos anos de 1990, talvez pelo facto de a FundaçãoNacional do Livro Infantil e Juvenil (FNLIJ), que até então havia premiado livros de poesia nas categorias criança e jovem ${ }^{8}$, em 1993, criar uma categoria específica para premiar livros desse género. Tantos medos e outras coragens (FTD, 1992), com um poema único de Roseana Murray distribuído ao longo das páginas ilustradas por Guto Lins, foi o primeiro livro premiado na categoria poesia, prenunciando, nesta década e nas seguintes, outras poucas publicaçóes que se aproximariam do subtipo álbum poema. Nesse mesmo ano de 1992, as Ediçôes Paulinas lançaram a Coleção Lua Nova, com direção editorial de Edmir Perrotti, passando a publicar brinquedos cantados e dramatizados da tradição oral popular brasileira, formas líricas tradicionais, com ilustraçóes de Cláudio Martins, destinados ao leitor iniciante, nos volumes Enquanto seu lobo näo vem (1992), O cravo brigou com a rosa (1994), Ciranda, cirandinha (1994), Teresinha de Jesus (1998), Atirei o pau no gato (1998).

Em 1999, oálbum poema Exercícios de ser criança (Salamandra, 1999), de Manoel de Barros, com bordados de Antônia Zulma Diniz e das irmãs Dumont sobre desenhos de Demóstenes Vargas, destacou-se pelo seu caráter criativo e inovador, seja na elaboração das ilustraçôes, seja na relação entre as componentes verbal e visual, seja pelo facto de conter não um ou vários, mas dois poemas: "O menino que carregava água na peneira" e "A menina avoada", cada um deles com seus versos distribuídos ao longo de duplas páginas. Ambas parcialmente narrativas, mas eivadas de metáforas, o que lhes confere elevado valor estético, as unidades poético-visuais contemplam em sua temática a dimensão potencializadora do imaginário infantil, evidenciada na tessitura tanto da palavra quanto das ilustraçóes feitas com bordados. Em "O menino que carregava água na peneira", a disposição sinuosa de alguns versos em harmonia com os movimentos ondulatórios sugeridos pelas formas visuais que os acompanham e o bordado das letras de versos finais do poema indicam a importância do design gráfico na inter-relação das componentes verbal e visual do texto híbrido.

Nos anos 2000, a editora Global passa a publicar álbuns poemas por meio da Coleção Magias Infantil, dirigida pela escritora Edla van Steen, integrada por brochuras com ilustraçóes de dupla página onde se distribuem versos de um poema único. Essas publicaçóes apresentam textos de diferentes

8 Livros de poesia premiados: na categoria criança, É isso ali (Salamandra, 1984), de José Paulo Paes e Carlos Brito; na categoria jovem, Fruta no ponto (FTD, 1986), de Roseana Murray e Sara Ávila. 
poetas brasileiros consagrados e ilustraçóes de autorias diversas. A conjugação de poemas preexistentes e ilustraçóes com temas e/ou elementos próximos ao universo infantil ou que possam interessar ao leitor criança estão presentes em Meus oito anos (Global, 2003), de Casimiro de Abreu e Fê, O pião (Global, 2003), de Guilherme de Almeida e Lélis, Trem de ferro (Global, 2004), de Manuel Bandeira e Gian Calvi, A pesca (Global, 2013), de Affonso Romano de Sant'Anna e Lúcia Hiratsuka. Em outras coleçōes desta mesma editora identificadas pelo nome do autor, também se opta pelo álbum poema, como $O s$ sinos (Global, 2012), de Manuel Bandeira e Gonzalo Cárcamo, e Os pescadores e suas filhas (Global, 2012), de Cecília Meireles e Cris Eich. Estas duas últimas publicaçóes apresentam-se muito mais bem cuidadas do que os volumes da Coleção Magias Infantil. Em ambas, editadas com encadernação capa dura e formato quadrado em grandes dimensóes ( $255 \mathrm{~mm} \times 255 \mathrm{~mm}$ ), as formas visuais ocupam toda a superfície das duplas páginas, a elas se sobrepondo os versos dos poemas. A editora Global investe, assim, desde o início dos anos 2000, em álbuns poemas de textos preexistentes reinterpretados através do trabalho de diferentes ilustradores.

Este caminho editorial de publicar poemas únicos em interação com imagens visuais tem sido seguido, ainda que em escala muito reduzida, por algumas outras editoras nos seus projetos de dar a conhecer ao leitor infantil poetas consagrados. É o caso de $A s$ pombas $^{9}$ (Formato Editorial, 2010), de Raimundo Correia e Clayton Junior, Poema pial (Larousse Júnior, 2011), de Fernando Pessoa e Rosinha, Conselho (Escrita Fina, 2013), de Fernando Pessoa e Odilon Moraes.

Nesta última década, a publicação de livros-álbum com um único poema, de poetas e ilustradores contemporâneos reconhecidos pela excelência de suas produçóes, ainda se mostra tímida se comparada à de livros-álbum antologias e poemários. Entre essas poucas produçóes destacam-se $A$ menina e o céu (FTD, 2013), de Leo Cunha e Cris Eich, Em cima daquela serra (Companhia das Letrinhas, 2013), de Eucanaã Ferraz e Yara Kono, Um dia, um rio, de Leo Cunha e André Neves (Pulo do Gato, 2016), e O mar de Cecília (Editora do Brasil, 2017), de Rosinha. Esses dois últimos livros receberam os prêmios FNLIJ 2017 e 2018, respetivamente, na categoria Poesia.

9 Como o poema foi musicado por Chiquinha Gonzaga, o livro, que integra a coleção Forrobodó, também confere crédito de autoria à compositora. 
Ao contrário de outros estudos em que são contempladas coletâneas poéticas ilustradas ${ }^{10}$, para este texto apenas foram selecionados volumes caracterizados por uma unidade significativa, integrando apenas um poema ou uma sucessão de poemas (ou fragmentos poéticos) unidos por um fio condutor claro e coerente, uma espécie de mote que é, em vários casos, assegurado pelo título ou por um desafio poético específico.

Os livros escolhidos para este estudo são, em Portugal, Letras \& Letrias $^{11}$, de José Jorge Letria e André Letria (Dom Quixote, 2005), Com o tempo ${ }^{12}$, de Isabel Minhós Martins e Madalena Matoso (Planeta Tangerina, 2014), e Eu Sou Eu Sei, de Ana Pessoa e Madalena Matoso (Planeta Tangerina, 2018); e, no Brasil, Palhaço macaco passarinho, de Eucanaã Ferraz e Jaguar (Companhia das Letrinhas, 2010) ${ }^{13}$, Bichos do lixo, de Ferreira Gullar (Casa da Palavra, 2013) ${ }^{14}$, e Ismália, de Alphonsus de Guimaraens e Odilon Moraes (Cosac Naify, $\left.2015[2006]^{15}\right)^{16}$. Trata-se de um conjunto de livros que permite não só perceber a evoluçáo destas publicaçóes ao longo de um período relativamente abrangente, como também explorar diferentes propostas de articulação entre texto e imagem, respondendo a diferentes objetivos.

\section{Portugal}

Do grupo de três livros portugueses selecionados, Letras \& Letrias (2005), de José Jorge Letria e André Letria, é o que mais se aproxima de uma coletânea poética, uma vez que os textos, semelhantes em termos formais e na proposta poética que apresentam, imitando as greguerías de Ramón Gómez de la Serna, se apresentam mais independentes entre si em termos temáticos. O título explora o jogo com a autoria (os apelidos dos criadores, pai e filho) e com a forma, tirando partido da paronímia, mas sugerindo também o diálogo e a cumplicidade no processo criativo. Os textos exploram todos uma certa irreverência na apropriação do mundo, procurando encontrar

10 A questáo da ilustraçáo da poesia, incluindo a de coletâneas de um ou vários autores, foi analisada em Ramos (2014).

11 Menção especial do Prémio Nacional de Ilustração em 2005 (Portugal).

12 Vencedor Prémio Autor SPA 2015/ Melhor Livro Infanto-juvenil (Portugal), Menção Honrosa na 19. a edição do Prémio Nacional de Ilustração 2014 (Portugal), Altamente Recomendável, na Categoria "Literatura em Língua Portuguesa", FNLIJ 2016 (Brasil).

13 Prémio FNLIJ 2011 na categoria Criança.

14 Prémio FNLIJ 2014 na categoria Criança.

15 A primeira edição do livro é de 2006, pela Cosac Naify. Em 2015, foi reeditado com algumas alteraçōes em seu estojo e capa. Com o encerramento das atividades da editora, em 2018 foi publicado pela SESI-SP Editora, com modificaçóes muito pontuais em alguns de seus paratextos.

16 Selo Altamente Recomendável na categoria Poesia, FNLIJ 2007. 
definiçóes para conceitos como o silêncio, a mentira ou a própria criação poética. Com recurso sistemático à metáfora e à analogia, os 26 fragmentos poéticos parecem desafiar um olhar poético sobre o real, seja ele o dia e a noite, o relâmpago, o gato, o sonho, o amor ou a liberdade, propondo outras formas de compreender e definir o mundo. $\mathrm{O}$ registro irônico ou mesmo satírico de alguns textos cruza-se com o sensorialismo poético de outros, a lembrar, até pela forma, o haiku: "a flor do lótus / tem o perfume da China / em cada pétala” (LETRIA \& LETRIA, 2005, s/p).

As ilustrações bem como o lettering, sempre diferente em cada página, têm implicaçôes no processo de leitura, colaborando na reinterpretação dos conceitos e na recriação visual das metáforas que os estruturam. As criaçôes de André Letria são, a este nível, particularmente bem conseguidas, antecipando já algumas das originais propostas de Se eu fosse um livro, outra publicação marcante desta dupla de autores, traduzida para várias línguas e publicada em muitos países. A proposta visual de Letras \& Letrias, lida em articulação com o texto, desafia o leitor a descobrir os pontos de contacto entre as imagens e o texto, uma vez que não o procura representar de forma fiel, mas alargar as suas possibilidades de leitura, procedendo ao seu comentário, recriação ou mesmo paródia. A distância interpretativa que o leitor tem de percorrer entre o texto e a imagem oscila significativamente ao longo do livro e transforma-se na atividade central da leitura articulada das duas linguagens. As variaçóes cromáticas, as alteraçóes constantes do lettering bem como a mudança da composiçáo das páginas favorecem igualmente as oscilaçóes de tom e registo, ora mais melancólico e introspetivo, ora mais divertido e irônico, causando surpresa constante.

Em Com o tempo (2014), de Isabel Minhós Martins e Madalena Matoso, o título é o mote poético para todas as páginas e segmentos textuais que compóem um livro que trata um dos temas mais recorrentes e universais da literatura (e da poesia): o topos da passagem e da inexorabilidade do tempo, aqui combinado com a questáo da mudança, ou seja, dos efeitos da passagem do tempo. A perceção da ação do tempo é o ponto nodal de toda a reflexão do sujeito poético, cujo olhar vai recaindo sobre o mundo e as coisas, desde as mais próximas e mais simples, às mais grandiosas e significativas, numa postura de contemplaçáo e deslumbramento sobre tudo o que o rodeia. Implicitamente, também se percebe a questấo da finitude da existência, nomeadamente a humana, o que permite concluir acerca da necessidade da valorização do que é importante e imutável, como a amizade, sugestão que termina o livro. A posição do sujeito poético é sobretudo a de alguém que descreve o que observa e tira conclusóes sobre essas evidências, mas que não tem completa certeza de todas as interpretaçóes, avançando hipóteses/ possibilidades, como se comprova pelo uso dos advérbios "talvez" ou da 
forma verbal "pode". As imagens dialogam com o texto, completando-o, mas também abrem e acrescentam outras leituras, propondo interpretaçóes possíveis para sugestóes mais ambíguas ou abstratas, como "o pequenino pode tornar-se gigante", "o difícil torna-se fácil", "perder algumas coisas", "ganhar outras", funcionando como possibilidades de concretização ou de exemplificação de algumas propostas textuais mais vagas. Tirando partido do jogo com formas geométricas e com uma paleta de cores relativamente contida, as imagens estimulam a reflexão sobre os textos, mas também criam surpresa no momento de virar de página, pelas variaçóes de perspetiva, pontos de vista ou enquadramento, mas também pela composição escolhida, criando diálogos entre páginas contíguas, por exemplo.

Finalmente, o volume Eu sou Eu sei (2018), de Ana Pessoa e Madalena Matoso, assume, no texto incluído na contracapa, a sua dimensão lírica, apresentando-se como um "poema". As dimensóes reduzidas, o formato quadrado e as ilustraçóes que exploram os contrastes cromáticos e um certo registo infantil não deixam muitas dúvidas sobre os destinatários preferenciais de um volume que é uma espécie de hino ou ode às descobertas da infância. $\mathrm{O}$ volume é composto por 52 segmentos textuais, todos iniciados pelo pronome pessoal "eu”, que surgem dispostos nas páginas em conjuntos de dois, quatro ou seis, criando, tanto do ponto de vista sonoro, como visual e gráfico, uma estrutura paralelística. O texto apresenta, por isso, inúmeras marcas formais do texto poético, como é o caso do verso e da rima, mas também da musicalidade e do ritmo, decorrentes da anáfora, das repetiçóes e do recursos sistemático aos monossílabos. Curiosamente, os segmentos não são apenas formados por pronome e verbo, na medida em que o leque de agrupamentos é muito mais diversificado, incluindo também nomes, advérbios, preposiçôes, interjeiçôes e onomatopeias. $\mathrm{O}$ recurso à pontuação é escasso, mas muito significativo, nomeadamente aos pontos de exclamaçáo que surgem no final.

As ilustraçóes revelam-se determinantes para o processo de leitura, uma vez que procedem à interpretação do texto, criando situaçóes e os seus agentes para cada um dos segmentos textuais. Assim, cabe à imagens situar a ação, desambiguar algumas propostas textuais, delimitando e circunscrevendo as possibilidades de leitura dos vários fragmentos. Além disso, centram o texto no universo infantil, conferindo-lhe um protagonismo que o texto, por si só, atendendo à sua estrutura, não consegue determinar. Também são as imagens que propóem diálogos e ligaçóes entre diferentes fragmentos e completam, do ponto de vista visual e da composição das páginas, o ritmo e a cadência do texto. Finalmente, ao recriarem várias figuras infantis para protagonizar as diferentes cenas, as ilustraçóes também atenuam o narcisismo do texto, propondo uma abertura do ensimesmamento infantil através da criação de muitos "eus" em vez de um único, como a leitura isolada do texto poderia sugerir. 
A análise do corpus brasileiro apresenta-se não pela ordem cronológica das publicaçóes, mas sim por suas possibilidades de cotejo, no que couber, com o corpus português.

Bichos do lixo (2013), de Ferreira Gullar, pode ser classificado como um álbum poemário, tal como Letras \& Letrias (2005), livro ao qual se assemelha, ainda, pelo fato de a sua proposta poética se inscrever no gênero greguería. No entanto, diferentemente do álbum poemário português, as 41 unidades de poemas-imagens distribuídas ao longo das duplas páginas do volume apresentam homogeneidade temática, já revelada no título da obra e reforçada pelo processo de criação plástico-poética desenvolvido por um só autor.

No seu prefácio, escrito como uma carta ao leitor, Ferreira Gullar explicita a proposta temática e plástico-poética do álbum: brincar com restos de diferentes correspondências recebidas pelos correios - "envelopes, convites, propagandas, revistas, calendários, catálogos e outros materiais em papel" (GULLAR, 2013, p. 3) -, combinando-as em fragmentos verbo-visuais de onde despontam bichos de todo tipo e feitio. Com as aparas de papéis coloridos e o emprego da técnica de colagem são criadas e recriadas formas visuais que dão vida a uma fauna existente ou inventada. Esse mesmo processo de criação plástico-poética já fora desenvolvido por Ferreira Gullar no álbum poemário Zoologia Bizarra (2010), publicado pela Casa da Palavra ${ }^{17}$, para algum tempo depois ser também empregado no álbum poema $A$ menina Cláudia e o rinoceronte (2013), da José Olympio Editora.

Em Bichos do lixo, as formas visuais mostram-se ora mais próximas do figurativo -reforçado principalmente pela parte verbal, como nas unidades poéticas "Sua majestade, o urubu" (p. 34-35) e "Jacarés" (p. 62-63), por exemplo - , ora mais próximas do abstrato - especialmente quando a parte verbal silencia a identificação do ser representado, como ocorre nas unidades "Ânimo alterado" (p. 14-15) e "É o tangolomango" (p. 76-77), alargando as possibilidades imaginativas do leitor, que, em ambos os casos, é instado a explorar a relação simbiótica entre as partes verbal e visual das unidades poéticas, por serem ambas imprescindíveis para a sua interpretação e fruição. $\mathrm{O}$ imbricamento entre palavra e imagem é reforçado, ainda, pelo uso de diferentes cores e pela espacialização não convencional da parte verbal, que, em algumas unidades, é disposta de modo a assemelhar-se a certos atributos das personagens representadas visualmente. É o que acontece em "Cobra-novelo" (p. 6-7), "O manco" (p. 32-33), "Ave de briga” (p. 40-41), "Cobra-Norato” (p. 68-69),

17 Zoologia Bizarra também foi publicado em Portugal em 2011 pela Editorial Caminho, sendo recomendado pelo PNL 2017 para leitura dos 9-11 anos. 
"Habitantes da água" (p. 74-75), significativos indícios da filiação do autor ao neoconcretismo no início de sua trajetória poética. Outro recurso que tem lugar em algumas unidades poéticas é o da intertextualidade, desafiando o leitor a ativar seu repertório e conhecimento textual-discursivo, como ocorre em "O gato que ri” (p. 30-31), "Pássaro Quixote" (p. 60-61), "Cobra-Norato" (p. 68-69). Todos esses recursos colaboram para a intensificação das metáforas e ironias exploradas na parte verbal das unidades poéticas deste livro álbum.

Assim como Com o tempo (2014) e Eu sou Eu sei (2018), Palhaço macaco passarinho (2010) é um álbum poema. As suas ilustraçóes assinadas por Jaguar associam-se ao texto poético de Eucanaã Ferraz na primeira edição deste livro-álbum, uma brochura formato retrato $190 \mathrm{~mm}$ x $250 \mathrm{~mm}$, com a prevalência das ilustraçóes nas suas duplas páginas.

Aparentemente de forma simples e despretensiosa, a temática deste álbum poema trata dos anseios de felicidade e liberdade inerentes ao ser humano. Em sua parte verbal, o sujeito poético, que se apresenta como uma pluralidade de vozes ao empregar a expressão "a gente" em vez de um pronome pessoal de primeira pessoa do singular, constrói analogias que ora se sucedem, ora se entrecruzam, através das personagens que dáo título ao livro.

A aparente simplicidade dos versos curtos, constituídos de oraçóes absolutas que se assemelham ao modo de as crianças pequenas desenvolverem as suas primeiras tentativas de produção do texto escrito, é o que permite ao leitor ir estabelecendo os sofisticados nexos propostos pelo poeta por meio das analogias. Tais analogias vão sendo construídas através de símiles, metáforas e paralelismos produzidos a partir das qualidades atribuídas às personagens-título, a maior parte delas com conotação positiva - "alegre", "leve", "colorido" -, ainda que "triste" também as defina. Essas qualidades são o que as une entre si, numa intricada rede de correlaçóes, definidora da essência humana representada pelo sujeito poético plural. A leveza, atributo do passarinho, acaba por se revelar a principal qualidade partilhada entre palhaço, macaco e sujeito poético. Associada à felicidade e à liberdade, tornase fulcral na construção do álbum poema.

A singeleza do texto poético advinda da economia verbal que o caracteriza também está presente nas ilustraçóes de estilo caricatural e jocoso, que prescinde de cenários e se concentra na representação das personagens. As cores de fundo das páginas e as que são aplicadas para destacar certas partes das personagens muito provavelmente resultam do trabalho dos profissionais que assinam o projeto gráfico do livro, Raul Loureiro e Claudia Warrak. As analogias e os paralelismos constitutivos da parcela verbal do álbum também estáo presentes na sua parcela visual, em que certos elementos icônicos se repetem na caracterização das diferentes personagens, renovando-se e ressignificando-se. É o caso da boca do palhaço, ora alegre, ora triste, que 
também está no macaco e no homem, da careta mostrada com a língua projetada para fora da boca, ou do voo de cada uma dessas personagens. Representado por uma caricatura do poeta, o homem, que corresponde à voz plural do sujeito poético inscrito na parcela verbal do texto, é o mesmo que aparece retratado no peritexto com os dados biográficos dos autores do livro. Esse peritexto verbo-visual traz o autorretrato do ilustrador e o retrato do poeta-personagem.

Construído como um livro-acordeão, disponibilizado numa caixa cartonada protetora que envolve o objeto livro desdobrável, Ismália (Cosac Naify, 2015 [2006]) corresponde à transformação em livro de um poema de Alphonsus de Guimaraens, pseudônimo de Afonso Henrique da Costa Guimarães, poeta simbolista brasileiro que viveu na viragem dos séculos XIX e $\mathrm{XX}$, inicialmente publicado no livro póstumo Pastoral aos crentes do amor e $d a$ morte, em 1923. Concebida e criada por Odilon Moraes, ilustrador e designer gráfico contemporâneo, a edição em estudo identifica-se com o subtipo álbum poema a partir de texto poético preexistente (NEIRA-PIŃEIRO, 2012).

A nova versão em acordeão do poema propóe a sua leitura vertical, uma vez que o livro se desdobra de cima para baixo, em articulação com a forma tradicional da poesia. Originalmente escrito em cinco quartetos, nesta edição o poema transforma-se num conjunto de dez dísticos distribuídos nas duplas páginas, que têm as suas cenas visuais ora delimitadas pela presença de moldura ora não. Tal recurso gráfico marca a alternância dos planos adotados pelo ilustrador, que imprimem movimento a cada virada de dupla página. A mudança de enquadramento é responsável, portanto, pela aproximação ou distanciamento do olhar do leitor em relação à personagem e aos elementos centrais e simbólicos do cenário: a torre, a lua e o mar. A aproximação é assinalada pela moldura branca em torno da cena apresentada em plano de detalhe, enquanto o distanciamento é marcado pela imagem sangrada da cena visual, em plano geral, o que constitui uma estratégia relevante para a produção de sentidos. Trata-se de um álbum poema que, do ponto de vista do conteúdo, é justamente dominado pela relação entre o céu (em cima) e o mar (embaixo), os dois elementos centrais que dividem a atenção da protagonista, que dá nome ao poema e ao livro, condenando-a à loucura e ao suicídio final. Nesse sentido, a nova distribuição dos versos e sua conjugação com as cenas visuais criadas incorporam as antíteses constitutivas do poema, reforçando as polaridades céu/mar, subir/descer, perto/longe.

O ilustrador-designer recorre a uma paleta de cores muito contida, em perfeita harmonia com o tom poético do texto e o ambiente noturno (e soturno) que ele apresenta, dominada pelos tons sépia, que vão do mimético ao simbólico, intensificando o teor dramático e melancólico do álbum poema. 
Não sendo as publicações mais comuns no segmento do livro-álbum, mais dominado pelos textos assumidamente narrativos, os textos poéticos parecem, contudo, pela contenção que os caracteriza, perfeitamente adaptados às exigências deste formato, não por acaso classificado, pelo próprio Maurice Sendak, como poema visual ${ }^{18}$, acrescentando o criador que

Um livro-álbum de imagens não é apenas o que a maioria das pessoas pensa que é - uma coisa fácil, com muitas ilustraçóes, destinado à leitura por crianças pequenas. Para mim, é uma coisa muito difícil de fazer, como trabalhar numa forma poética complicada e desafiadora. Exige tanto que é necessário estar no topo da situação o tempo todopara, finalmente, conseguir algo tâo simples e táo organizado - táo perfeito - que pareça que foi criado muito rapidamente. Uma costura visível e perde-se o jogo ${ }^{19}$ (SENDAK apud LANES, 1984, p. 109).

Esta dimensão poética que, no entender de Sendak, parece transversal a todos os livros-álbum, associada à exiguidade e à sobriedade do texto, bem como à existência de espaços em branco, é particularmente relevante no livro-álbum lírico, na medida em que a sugestão contemplativa, decorrente da ausência de ligaçôes de tipo causa-efeito ou de sucessão cronológica, transforma cada dupla página numa espécie de verso verbo-icônico, tirando partido das possibilidades do diálogo entre as duas linguagens que compóem o livro-álbum, mas também de tensão entre elas.

Também nesta linha de associação da criação do livro-álbum à poesia, Wolfenbarger e Sipe sublinham que

Os autores de livros-álbum são como poetas em busca de uma linguagem concisa, evasiva e evocativa que capte a essência do que as personagens estáo experimentando. Os melhores autores/ilustradores de livros-álbum estão em sintonia com as necessidades e os desejos humanos. Os melhores autores e ilustradores de livros-álbum iluminam lugares dentro das experiências do leitor e lançam luz sobre aqueles cantos sombrios que se escondem ao lado com os caminhos para novos entendimentos. $\mathrm{O}$ novo entendimento pode ser auto-entendimento ou uma maior consciência do lugar de cada um no mundo $^{20}$ (WOLFENBARGER \& SIPE, 2007, p. 279-280).

18 "a true picture book is a visual poem" (SENDAK apud LANES, 1984, p. 110).

19 Traduçấo das autoras de: "A picturebook is not only what most people think it is - an easy thing, with a lot of pictures in it, to read to small children. For me, it is a damned difficult thing to do, like working in a complicated and challenging poetic form. It demands so much that you have to be on top of the situation all the time, finally to achieve something so simple and so put together - so seamless - that it looks as if you knocked it off in no time. One stitch showing and you've lost the game".

20 Tradução das autoras de "Picturebook authors are like poets searching for concise, spare, evocative language that captures the essence of what the characters are experiencing. The best picturebook authors/ 
As publicaçôes portuguesas de livros-álbum líricos parecem privilegiar, nos últimos anos, o subtipo álbuns poemas produzidos por autores contemporâneos, ainda que o número de álbuns poemários também seja significativo. Já no Brasil observa-se uma forte tendência de publicação tanto de álbuns poemários quanto de álbuns poemas com textos poéticos previamente existentes. Em ambos os países, contudo, já se verifica uma tendência crescente para se oferecer, especialmente ao público leitor infantil, produçóes editoriais que dáo destaque ao álbum poema a partir de texto poético criado especificamente para o álbum, no qual a ilustração pode estimular "a imaginação, funcionando como uma espécie de prólogo visual ao texto, gerando uma multidão de impressóes vagas e cativantes, ou seja, criando expectativas em relação a ele" (CAMARGO, 1998, p. 24). No corpus de análise deste artigo, três das seis publicaçôes são álbuns poemas de autores contemporâneos, o que parece confirmar esta tendência.

Os textos poético-icônicos analisados, ao procurarem dar voz ao universo infantil, propóem visões do mundo marcadas por olhares inaugurais, assumidamente originais e singulares, desafiando as convençóes e propondo uma espécie de retorno a uma certa ingenuidade dos primórdios, capaz ainda de se deslumbrar com a simplicidade do quotidiano. Ao mesmo tempo, esse olhar e essa voz não deixam de estabelecer uma postura crítica, mesmo se implícita, com o universo adulto.

Além do mais, a apresentação dos poemas neste formato editorial parece facilitar a aproximação entre os leitores e a poesia, quebrando alguns preconceitos e barreiras que tradicionalmente se interpóem entre ambos, surgindo as imagens e o design gráfico como forma de mediação por excelência. A poesia cruza-se com o universo dos leitores mais pequenos quase sem que eles deem por isso, tomando muitas vezes a forma de um jogo onde as palavras e as ilustraçôes parecem ganhar novos significados.

illustrators are in tune with human needs and desires. The best picture-book authors and illustrators illuminate places within the reader's experiences and cast light in those shadowy corners that lurk alongside the pathways to new understandings. The new understanding can be self-understanding or a greater awareness of one's place in the world". 
Referências

BORDINI, M. G. Poesia infantil. São Paulo: Ática, 1986.

CAMARGO, L. H. Poesia infantil e Ilustração: estudo sobre "Ou isto ou aquilo" de Cecilia Meireles. (Dissertação de Mestrado em Teoria Literária) UNICAMP, Campinas, 1998.

FERRAZ, Eucanaã \& JAGUAR. Palhaço macaco passarinho. São Paulo: Companhia das Letrinhas, 2010.

GLAZER, J. I. \& Lamme, L. L. Poem Picture Books and Their Uses in the Classroom. Reading Teacher. v. 44, n. 2, p. 102-09, 1990

GUIMARÁES, Alphonsus de \& MORAES, Odilon. Ismália. São Paulo: Cosac Naify, 2015 [2006].

GULLAR, Ferreira. Bichos do lixo. Rio de Janeiro: Casa da Palavra, 2013.

KESLER, T. Evoking the World of Poetic Nonfiction Picture Books. Children's Literature in Education. v. 43, n. 4, p. 338-354, 2012. doi:10.1007/s10583012-9173-4.

LANES, S. G. The art of Maurice Sendak. New York: Abradale Press/Harry N.Abrams, Inc., 1984.

LETRIA, José Jorge \& LETRIA, André. Letras \& Letrias.Lisboa: Dom Quixote, 2005.

MARTINS, Isabel Minhós \& MATOSO, Madalena. Com o tempo. Carcavelos: Planeta Tangerina, 2014.

NEIRA-PIÑEIRO, M. del R. Poesía e imágenes: una nueva modalidad de álbum ilustrado, Lenguaje y Textos. v. 35, p. 131-138, 2012.

NEIRA-PIŃEIRO, M. del R. Can Images Transform a Poem? When I Heard the Learn'd Astronomer: An Example of a Poetry Picturebook, New Review of Children's Literature and Librarianship. v. 19, n. 1, p.14-32, 2013. doi: $10.1080 / 13614541.2013 .751290$

NEIRA-PIÑEIRO, M. del R. Posibilidades de secuenciación de las imágenes en el álbum ilustrado lírico, Ocnos - Revista de Estudos sobre Lectura. v. 17, n. 1, p. 55-67, 2018. doi: 10.18239/ocnos_2018.17.1.1527

PESSOA, Ana \& MATOSO, Madalena. Eu sou eu sei. Carcavelos: Planeta Tangerina, 2018.

RAMOS, A. M. Apontamentos para uma poética do álbum contemporâneo, In: Roig Rechou, B. A; Soto López, I.; Rodríguez, N. (eds.). O Álbum na Literatura Infantil e Xuvenil (2000-2010). Vigo: Edicións Xerais de Galicia, 2011. 
RAMOS, A. M. Ilustrar poesia para a infância: entre as rimas cromáticas e as metáforas visuais. Ocnos - Revista de Estudos sobre Lectura, n. 11, p. 113-130, 2014. Disponível em: <http://www.revista.uclm.es/index. php/ocnos/article/view/447>

RUVE, D. Poetry in picturebooks. In: KUMMERLING-MEIBAUER, Bettina (ed.), The Routledge Companion to Picturebooks. Oxon/New York: Routledge, 2018, p. 246-259.

SILVA, S. R. da. Ilustração e poesia: para uma definição/caracterização do álbum poético para a infancia, In: SILVA, S.R. Entre Textos. Perspectivas sobre Literatura para a infância e juventude. Porto: Tropelias \& Companhia, 2011, p. 273-284.

SILVA, S. R. da \& SASTRE, M. S. O álbum poético em português e em espanhol:sinergia estética entre palavras e ilustrações, Revista Brasileira de Educação. v. 22, n. 71, p. 1-24, 2017. Disponível em: <http://dx.doi.org/10.1590/S1413$24782017227148>$

WOLFENBARGER, C. D. \& SIPE, L. A Unique Visual and Literary Art Form: Recent Research on Picturebooks. Language Arts. v. 84, n. 3, p. 276-280, 2007.

Ana Margarida Ramos. É doutorada em Literatura e Professora Auxiliar com Agregaçáo do Departamento de Línguas e Culturas da Universidade de Aveiro, onde leciona disciplinas da área da Literatura Portuguesa e da Literatura para a Infância. Integra o Centro de Investigação em Línguas, Literaturas e Culturas (CLLC) da Universidade de Aveiro. Integra, como investigadora, a equipa da Rede Temática de Investigação Ibérica "As Literaturas Infantis e Juvenis do Marco Ibérico e Iberoamericano".

E-mail: anamargarida@ua.pt

Margareth Silva de Mattos. É professora de Ensino Básico da Universidade Federal Fluminense (UFF-Brasil). Doutora em Estudos de Linguagem da mesma Universidade. Integrante dos grupos de pesquisa LeiFEn (Leitura, Fruição e Ensino), e LELIS (Leitura, Literatura e Saúde: inquietaçóes no campo da produçáo do conhecimento), ambos cadastrados no Diretório dos Grupos de Pesquisa no Brasil.

E-mail: margarethuffmattos@gmail.com 